Article

\title{
Geospatial Data Utilisation in National Disaster Management Frameworks and the Priorities of Multilateral Disaster Management Frameworks: Case Studies of India and Bulgaria
}

\author{
Tarun Ghawana $^{1}\left(\mathbb{D}\right.$, Lyubka Pashova $^{2, *(D)}$ and Sisi Zlatanova ${ }^{3}(\mathbb{D}$ \\ 1 Independent Researcher, New Delhi 110078, India; tarungh@gmail.com \\ 2 National Institute of Geophysics, Geodesy and Geography, Bulgarian Academy of Sciences, \\ Acad. Georgi Bonchev Str., Bl. 3, 1113 Sofia, Bulgaria \\ 3 GRID, School of Built Environment, UNSW Sydney, Red Centre Building, Kensington, NSW 2052, Australia; \\ s.zlatanova@unsw.edu.au \\ * Correspondence: lpashova.niggg@geophys.bas.bg; Tel.: +359-(0)-2-979-3349
}

\section{check for} updates

Citation: Ghawana, T.; Pashova, L.; Zlatanova, S. Geospatial Data Utilisation in National Disaster Management Frameworks and the Priorities of Multilateral Disaster Management Frameworks: Case Studies of India and Bulgaria. ISPRS Int. J. Geo-Inf. 2021, 10, 610. https:// doi.org/10.3390/ijgi10090610

Academic Editors: Marcin Kulawiak and Wolfgang Kainz

Received: 12 August 2021

Accepted: 12 September 2021

Published: 15 September 2021

Publisher's Note: MDPI stays neutral with regard to jurisdictional claims in published maps and institutional affiliations.

Copyright: (c) 2021 by the authors. Licensee MDPI, Basel, Switzerland. This article is an open access article distributed under the terms and conditions of the Creative Commons Attribution (CC BY) license (https:// creativecommons.org/licenses/by/ $4.0 /)$.

\begin{abstract}
Facing the increased frequency of disasters and resulting in massive damages, many countries have developed their frameworks for Disaster Risk Management (DRM). However, these frameworks may differ concerning legal, policy, planning and organisational arrangements. We argue that geospatial data is a crucial binding element in each national framework for different stages of the disaster management cycle. The multilateral DRM frameworks, like the Sendai Framework 20152030 and the United Nations Committee of Experts on Global Geospatial Information Management (UNGGIM) Strategic Framework on Geospatial Information and Services for Disasters, provide the strategic direction, but they are too generic to compare geospatial data in national DRM frameworks. This study investigates the two frameworks and suggests criteria for evaluating the utilisation of geospatial data for DRM. The derived criteria are validated for the comparative analysis of India and Bulgaria's National Disaster Management Frameworks. The validation proves that the criteria can be used for a general comparison across national DRM.
\end{abstract}

Keywords: disaster; Sendai Framework; UNGGIM; DRM; geospatial information; SDI; comparative criteria

\section{Introduction}

The increased frequency of disasters and the resulting human and economic damages of massive scale are now global phenomena. The direct losses are a profound threat to the sustainability of economic and social gains made by the countries over time [1]. With the ever-expanding pace of urbanisation, these losses are going to increase as they affect more people and infrastructure [2]. Disasters in urban areas have a high intensity of damage, demanding the formulation and implementation of innovative advanced prevention strategies for disaster risk management (DRM) and disaster risk reduction (DRR) $[3,4]$.

Individual states around the world have developed national frameworks for disaster management. Some countries have regulated the response to all types of disasters and emergencies, for example, the United States of America [5] and Germany [6], while others have applied a specific regional approach, e.g., in Pacific countries [7] and the Andean countries [8]. Europe has made significant progress in establishing a legal framework to reduce disaster risks and strengthen existing frameworks in response to emerging threats [9]. However, the national frameworks are quite distinct, focussing on different aspects, and it becomes rather difficult to evaluate and compare the geospatial components. Therefore, establishing common assessment criteria using geospatial data would help to understand, compare and update existing frameworks and establish new ones. 
A common approach could be to examine the content of multilaterally accepted DRM frameworks and find a set of criteria with a greater possibility of conventional acceptability. The Sendai Framework [10] and the United Nations Committee of Experts on Global Geospatial Information Management (UNGGIM) Strategic Framework on Geospatial Information and Services for Disasters [11] are multilateral frameworks for DRM, including priorities dealing with governance to technical issues. The Sendai Framework acts as an umbrella strategic framework recommending national and local efforts for DRM. This framework identifies four main priorities for action: Understanding Disaster Risk, Enhancing Disaster Preparedness, Strengthening Disaster Risk Governance, and Investment in Disaster Risk Reduction. As a first significant agreement of the post-2015 development for DRM, the Sendai Framework does not provide specific guidance on how these priorities might be implemented, measured or ultimately achieved [12]. The UNGGIM framework, which also recommends national and local efforts, is partially based on the Sendai Framework. It focuses on geospatial spatial data, i.e., how to prevent or reduce the risk and impact of disasters using geospatial information and services. The priorities under the UNGGIM Strategic Framework are Governance and Policies, Awareness Raising and Capacity Building, Data Management, Common Infrastructure and Services, and Resource Mobilization [11]. However, this framework is still too general to reflect the geospatial technology in its detail.

Geospatial technologies are indispensable tools at every stage of the disaster management cycle - prevention, mitigation, preparedness, rescue, relief and recovery $[13,14]$. These technologies have evolved significantly over the years and have reached a wide range of users by developing interfaces and applications running on smartphones or portable devices [15]. Advances in earth remote sensing have contributed significantly to DRM [16]. The spatial and temporal resolutions of optical and radar sensors can fill the gaps in the DRM phases [16-18]. Terrestrial mobile units have empowered emergency response with real-time recordings, enriching the typical operational pictures and ensure adequate response during emergencies [19]. The development of Spatial Data Infrastructure (SDI) provides an integrated framework for effective data collection, storage, geoprocessing and sharing in support of DRM and recovery work [20-24]. In recent years, artificial intelligence and big data technology have found wide application in the quantitative understanding of natural phenomena in the Earth sciences, which can result in disasters. An effective crossplatform distributed computing framework with a focus on large-scale spatial data, called GeoBeam, is presented in [25]. International collaboration on research and developments for DRM has resulted in numerous frameworks for data sharing and integration [26-29]. Much attention has been given to approaches for creating user-dedicated maps and visualisations to support decision-making at the global and local levels [30,31]. Ontology-based approaches for semantic identification and filtering information concerning tasks and responsibilities have been reported [32-34]. 3D information has been discussed extensively in the context of disaster management [35]. The establishment and progress of 3D standards such as CityGML, Industrial Foundation Classes (IFC), IndoorGML and Land Administration Domain Model (LADM) made possible better structuring and management of 3D data. Since early 2000, many articles have been published on using 3D for emergency response, and by now, many applications have become operational, allowing the integration of point clouds, 3D Geographic Information System (3DGIS), Building Information Modeling (BIM) and sensor information. This technology is expected to advance the geospatial enablement of the community, and therefore, better information sharing, alerts and governance are more likely to progress [36]. The countries and international organisations have taken steps towards imbibing the geospatial technologies in Disaster Risk Reduction (DRR) activities [37,38]. However, currently, there are no standardised criteria for evaluating geospatial data utilisation in DRM frameworks on a national and global scale.

The paper seeks to address this need using the priorities of the two internationally accepted multilateral frameworks for DRM discussed above. A set of criteria was derived from the interrelated priorities of the Sendai Framework [10] and the UNGGIM frame- 
work [11] for comparing the use of geospatial data in national DRM frameworks. In order to verify the selected criteria, a comparative study was conducted between the national DRM frameworks of two countries-India and Bulgaria. The two countries have significant differences in historical, social, economic, demographic, environmental conditions while facing almost similar significant natural hazards. It is illustrated that despite the differences, many similarities can be detected in the national DRM approaches of the two countries.

The rest part of this paper is structured as follows: An overview and an analysis of existing research work related to the use of geospatial data for DRM/DRR is presented in Section 2. Section 3 discusses the geospatial data criteria based on the priorities of the Sendai and UNGGIM frameworks in terms of activities and the translated products and services. Section 4 provides a brief overview of the two countries' physical, social, economic, historical and geographical characteristics. Section 5 presents the comparative analysis between the Indian and Bulgarian DRM Frameworks. In Section 6, the analytical results are discussed. Finally, Section 7 concludes the research by summarising overall findings and presents recommendations for using the derived criteria.

\section{Related Research}

Disaster management is defined as a body of policy and administrative decisions, operational activities, actors and technologies about different disaster phases at various levels. DRR needs to be mainstreamed and integrated within and across all sectors and further develop national and local laws, regulations and public policies. These regulations and policy measures define the roles and responsibilities of the public and private sector, guiding them towards addressing disaster risk [39]. Key institutions raised at different levels for policy guidance, capacity development and emergency response, and equipped with legal and policy framework mandates are analysed in [40]. The ratifying of the Natural Disaster Relief Act 1982 in Nepal is discussed in [41], leading to establishing central, regional, district and local level Natural Disaster Relief Committees and setting out organisational responsibilities. This legal frame includes assigning the Ministry of Home Affairs (hereafter the Home Ministry) responsibility for national policies formulation and implementation. The paper also discusses National Action Plan for Disaster Risk Management, 1996, National Strategy for Disaster Risk Management in Nepal (Draft), 2008. It is necessary to study the role-played and potential involvement of international law as a productive tool in DRR and in creating and dealing with hazards, vulnerabilities and capacity [42]. Aronsson-Storrier [43], referring to the Sendai Framework, emphasises the DRR as a common concern for the States and the extent of effective enhancement and implementation of national DRR policies and measures by developing countries in their respective circumstances and capabilities.

Through the years, several authors have compared the DRM frameworks of various countries. The DRMs of Chile and Ecuador are compared in [44] to investigate the appropriateness of global approaches. The DRM practices in Bucharest, Mexico and Istanbul regarding legislation, planning, financial resources, organisational structures, risk assessment, early warning, education, training and research to investigate the risk assessment plans are considered in [45]. Similarly, Banerji et al. [46] compared practices in Japan and India, and a comparison of seven megacities is presented in [47]. These last two studies examine the legal, policy, planning and institutional components to guide the comparison. Furthermore, the components for policy and planning include the DRR strategy and participation in regional and international activities, programs, networks and structures. Various formulations of rules that govern the same object in Japan and Indonesia are compared in [48]. However, these comparisons do not focus on geospatial data.

Many studies analyse geospatial data activities supporting DRM. For example, Bhanumurthy et al. [29] focused on geospatial data generation, integration, processing, interoperability, while Mansor et al. [49] focused on multi-criteria analysis and model/system development in the context of DRM. Based on the multinational earthquake prediction research, Stevenson [50] emphasizes the need for developing a continuously operating 
geo-watching system with a rules-based alert schedule that can link scientific assessments to adequate action for people and society in emergencies. The United Nations Conference on Trade and Development (UNCTAD) study [51] described how geospatial technologies could contribute to DRM activities, including hazard, risk, damage assessment, land use planning, reconstruction planning, early-warning, education, training and awareness, logistics and resource planning. The following GIS elements were taken into account: GIS database, web-mapping, GIS analysis, and advanced modelling tools with GIS analysis, Decision Support System (DSS) and SDI. The United Nations (UN) Handbook [52] highlights the need for data viewing applications such as Google Earth or a web-based GIS to communicate disaster-related information. It emphasises that the geospatial information management is essential for effective evidence-based decision-making. Combining administrative and socioeconomic data with hazard-related data enables the modelling of risks and DRR activities. The UN Handbook also mentions cartographic products (maps and charts) generated and distributed in digital formats, satellite and aerial remote sensing products and Global Positioning System (GPS) data.

Another group of studies research the geospatial data activities only of a category serving the specific purposes under DRM. It is argued by [51-53] that data collection and management are required for hazard, vulnerability, risk and capacity (HVRC) assessment. The need for data collection and management in the context of DRM for storing the datasets is also highlighted in $[23,28]$, so that data can be efficiently retrieved through queries for editing or analysis. Hazard-risk modelling and simulation using geospatial datasets and sensor measurements are emphasised in Mansor et al. [49] as they can simulate and predict the severity, affected area or provide post-disaster evaluations for DRM. In [54], attention is paid on how best to support the development or combination of SDI(s) for use in disasters. National Spatial Data Infrastructure (NSDI) or SDI facilitates the integration and standardisation of data retrieval and the access to the data and dissemination of information between the responsible DRR institutions and other stakeholders [23,29,52]. Mansourian et al. [55] has also emphasised the utility of SDI/NSDI for the decision-makers regarding DRM. Sterlacchini et al. [23] argue that a Spatial Decision Support System (SDSS) or DSS is a core module in DRM because it allows creating a common operational picture, and formulating and executing instructions for every responsible person involved in emergency management. The importance of SDSS enabling geospatially informed decisionmaking is also discussed $[29,56]$. The contribution of this concept in risk management and planning is supported [57], for example, in flood-risk related strategies [58]. The role of a DSS and GIS as a spatially integrated policy infrastructure to support the integration of spatial planning with flood-risk management is also highlighted [20].

The literature review clearly shows that geospatial data cut across different DRM interventions and contribute to various processes through data generation, sharing, scenario generation from simulations/modelling and decision support systems. We found that in individual studies, some elements are essential in the context of geospatial data and services that address individual stages of the overall DRM process. Such elements include Data Collection and Management, Data Integration and Standardization, SDI/NSDI, Risk Modelling and Simulation, DSS/SDSS and others. Based on the literature analysis, we argue that geospatial data should be formalised through a common set of criteria supported by multilateral agreements.

\section{Selection of Criteria}

The Sendai and UNGGIM multilateral initiatives provide the strategic guidelines that are expected to be followed by the countries that have ratified these agreements. A significant component of DRM is determined by how countries integrate DRR into activities defined in national frameworks, laws, regulations and policies to make sustainable progress in reducing this risk. The aim is to strengthen the institutions, to improve the legal and regulatory frameworks through which public policies related to this topic are managed, coordinated and controlled. Defining the DRM framework at a national level is 
a coherent process that integrates activities for formulating national policy, strategy and plans at the appropriate level of organisational management-from national and district to local/municipal. In this regard, we carried out a detailed investigation of the Sendai and UNGGIM frameworks and compared their priorities point-by-point, looking for how they reflect the spatial context in terms of geospatial data or geographic information. We seek to identify how the essential components of the defined priorities, which should be the guidelines of the national frameworks of individual countries, reflect the spatial context in the individual activities on a legal basis, policy making, planning formulations and organisational mandates. The established general connections between the priorities of the two frameworks through regulated recommended activities from national to local level are shown in Figure 1.

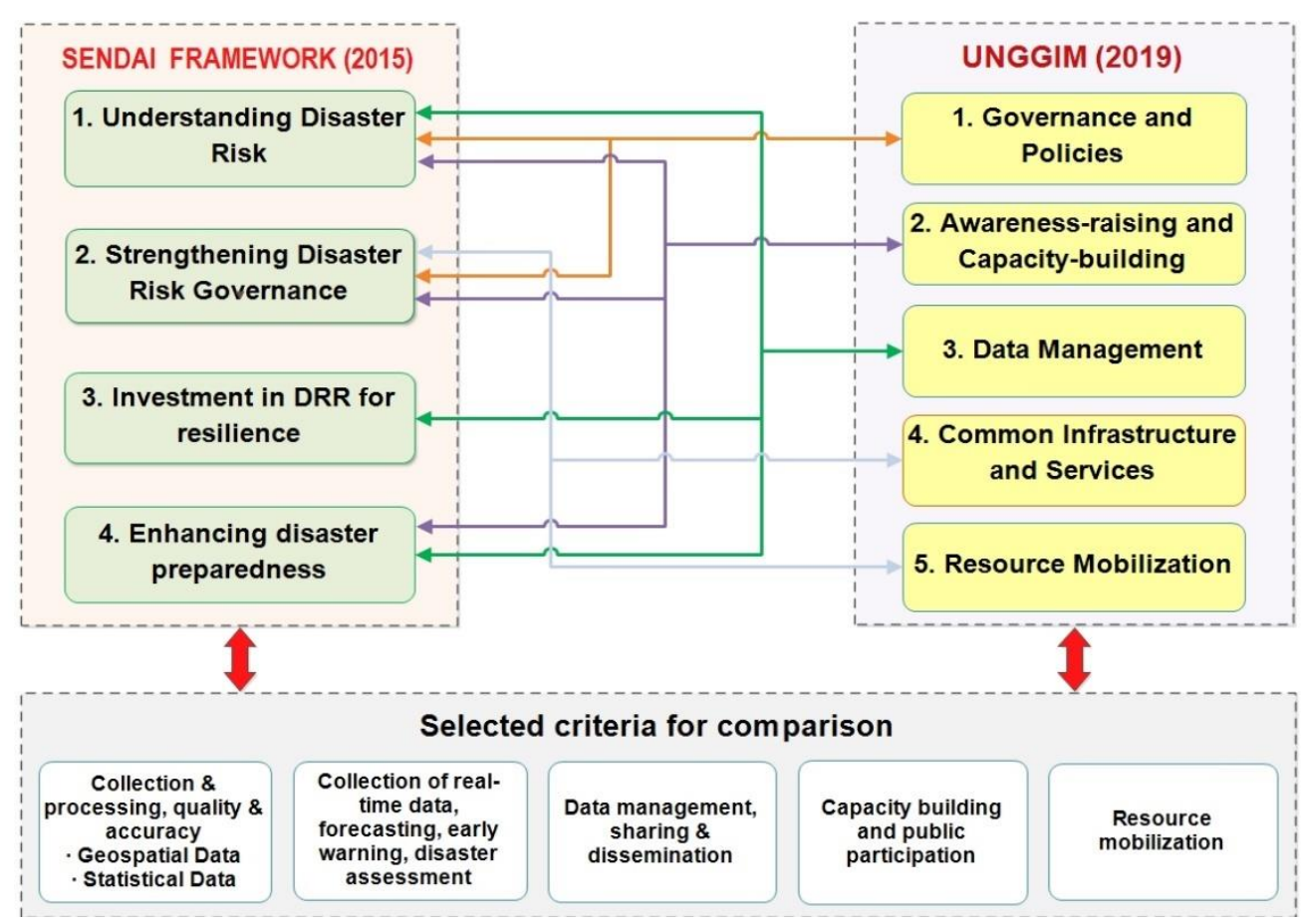

Figure 1. The linked priorities of the two frameworks based on recommended national and local level interventions regarding spatial data.

Our analysis shows that Priority 1 and 2 of the Sendai Framework and Priority 1 of the UNGGIM framework are linked because the technical capacity assessment to deal with the identified risks could be explained in the context of availability, accessibility and usage of quality geospatial information and services. The priorities explain the two-way relationship between policy development and information. Systematic binding efforts could be applying the risk information in all its dimensions to develop and implement DRR policies.

Priority 1, 2 and 4 of the Sendai Framework are linked with Priority 2 of the UNGGIM framework. Under these priorities, strategies include coordination forums to build and strengthen public education, awareness and knowledge of the disaster risk information, data collection and information dissemination through social media and other platforms.

Priority 1, 3 and 4 of the Sendai Framework are linked with Priority 3 of the UNGGIM framework. Under these priorities, developing a joint and accessible database system of baseline geospatial information and services can encourage their use and enhance DRM-related assessments. Developing, updating and disseminating hazards, vulnerability and disaster risk assessment maps, and other information products to decision-makers and communities can serve as crucial inputs to the national and local DRM plans and frame relevant projects, programs and activities. Rural development planning, urban planning, land degradation assessments, multi-hazard and multi-sectoral forecasting and 
early warning systems development are the business use cases for disaster risk maps and assessment templates to answer high-level process needs. It includes systematic data management as collection, analysis, dissemination and usage for different user needs, access to real-time data, disaster loss accounting, and understanding the economic, social, health, education, environmental and cultural heritage impacts. The risk information is a part of the recommended interventions in geospatial data and statistics obtained from traditional, local or scientific knowledge. This risk information can be used and applied to develop and implement DRM policies, strategies, plans and programmes in all its dimensions of hazard, vulnerability, capacity and exposure.

Priority 2 and 4 of the Sendai Framework are linked with Priority 4 of the UNGGIM framework. Under the recommended interventions, the system-level interoperability, achieved through data management guidelines and geospatial information standards, can make it possible to adopt and implement the national and local strategies and plans across different timescales in the context of DRR and prevention resilience strengthening. In addition, a remaining unsurpassed priority of the UNGGIM for "resource mobilisation" is also considered to include all other relevant criteria.

Subsequently, a set of geospatial criteria is derived from the priorities of the Sendai [10] and UNGGIM [11] frameworks. Based on the activities related to geospatial technologies, data and information, we have identified common criteria that collectively represent the main activities that each country should undertake to create the recommended products and services to manage disaster risk, developing a national conceptual DRM framework. Table 1 presents the recommended products and services as derived from Sendai and UNGGIM, the integrated generic activities, which are then used as criteria.

Table 1. Spatial data criteria based on the priorities of the two frameworks.

\begin{tabular}{|c|c|c|c|}
\hline S. No. & Translated Products and Services & Activity & Criteria \\
\hline 1 & $\begin{array}{l}\text { - Base maps (topographic maps, geological data, land-use } \\
\text { map, Elevation data) satellite images, LIDAR or } \\
\text { Photogrammetric } \\
\text { Disaster risk maps (simulation, prediction) and } \\
\text { assessment templates (regulation, procedure for } \\
\text { reaction), (maps, documents) }\end{array}$ & $\begin{array}{l}\text { Collection and processing, quality } \\
\text { and accuracy } \\
\text { - } \quad \text { Geospatial Data } \\
\text { - } \quad \text { Statistical Data }\end{array}$ & 1. Existing data \\
\hline 2 & $\begin{array}{ll}\text { - } & \text { Situational awareness (maps, systems) } \\
\text { - } & \text { Real-time services (alert messages, prediction maps) } \\
\text { - } & \text { (documents) } \\
\text { Disaster assessment regulations. Data (documents) } \\
\text { - } \quad \text { Displication software; Assessment (software) } \\
\text { Disaster losses-Disaster loss registers; (map, documents) }\end{array}$ & $\begin{array}{l}\text { Collection of real-time data, } \\
\text { forecasting, early warning, } \\
\text { disaster assessment }\end{array}$ & 2. Real-time data \\
\hline 3 & $\begin{array}{l}\text { - Database management systems (software) SDI and } \\
\text { Platforms (software/services) } \\
\text { - } \quad \text { Standards (documents) }\end{array}$ & $\begin{array}{l}\text { Data management, sharing and } \\
\text { dissemination }\end{array}$ & $\begin{array}{l}\text { 3. Data } \\
\text { management }\end{array}$ \\
\hline 4 & $\begin{array}{l}\text { Traditional, local or scientific knowledge (document) } \\
\text { - } \quad \begin{array}{l}\text { Public Education, Awareness and Knowledge Strategies } \\
\text { (document) }\end{array}\end{array}$ & $\begin{array}{l}\text { Capacity building and public } \\
\text { participation }\end{array}$ & $\begin{array}{l}\text { 4. Capacity } \\
\text { building }\end{array}$ \\
\hline 5 & $\begin{array}{l}\text { - Policy to maintain data, services and systems } \\
\text { (documents) }\end{array}$ & Resource mobilisation & $\begin{array}{l}\text { 5. Resources } \\
\text { mobilisation }\end{array}$ \\
\hline
\end{tabular}

The first criterion, Existing data, is related to geospatial and statistical data collection, processing, quality and accuracy, providing essential data as base maps or DRM-specific outputs as risk maps and assessment templates. The second criterion, Rea-time data, aims to cover the activities dealing with the dynamic information collection and analytics performed on the available information. For example, the forecasting, early warning and 
disaster assessment supports situational awareness through dynamic mapping or providing alerts and messages in real-time. The third criterion, Data management, regards all activities about data management, sharing and dissemination that could enable the development of database management systems and standards and establish SDI and platforms. The development of database systems and data sharing standards links to interoperability issues. The fourth criterion, Capacity Building, focuses on capacity building and public participation. These activities acknowledge the relationship between stakeholders and the information available with various knowledge sources, as local and traditional. The aim is to ensure inclusivity and active public participation, even crowdsourced or Volunteered Geographic Information. These activities enable the formulation of strategies for public awareness and education. The fifth criterion is Resource mobilisation. It is about making the resource available to maintain data, services and systems via policy acts. Such activities support the data-enabled services on governance and systemic level.

Each of the five groups of activities contributes and adds value by executing, enabling or facilitating the DRM interventions at various stages. Therefore, the five criteria can be utilized for comparing national DRM frameworks. The following sections present a study carried out on the example of India and Bulgaria.

\section{Use Cases-India and Bulgaria}

We have selected these two countries because they are quite different (see Table 2). India and Bulgaria are geographically located in two different continents with a significant distance between them; they have vastly different physical, economic and demographic characteristics. Nevertheless, they both share some natural disaster risks of similar types, including floods, landslides and storms. Besides the spatial variations of hazards, vulnerabilities and risk, the international boundaries raise the complexity of disaster events. The classic case is the Kosi river floods in India, originating in Nepal and flowing towards the Bay of Bengal through the Indian State of Bihar. The devastating floods ravage the lower plains of the Bihar State almost every year, destroying vast agricultural lands, settlements, bridges, and other infrastructure. In Bulgaria, similar devastating flood events are observed along the Danube, Maritsa, Arda, Tundja, Struma and Mesta rivers. Bulgaria also experiences fires on the land borders with Serbia, Northern Macedonia, Greece and Turkey.

Table 2. Characteristics of India and Bulgaria.

\begin{tabular}{|c|c|c|}
\hline Descriptor & India & Bulgaria \\
\hline Location & Located in Asia & Located in Europe \\
\hline Member of a union & $\begin{array}{l}\text { Independent of any regional bloc } \\
\text { controlling the borders, trade and } \\
\text { other policies }\end{array}$ & $\begin{array}{l}\text { Member of the European Union as a regional bloc and } \\
\text { adheres to its controlling regulations. }\end{array}$ \\
\hline Economy & Developing economy & Developed economy \\
\hline Population & $\begin{array}{l}\text { Second highest populated country in } \\
\text { the world }(1,380,004,000)\end{array}$ & Comparatively very small population $(6,951,000)$ \\
\hline Area & $\begin{array}{l}\text { One of the largest countries in the } \\
\text { world }(3,287,259 \mathrm{sq} . \mathrm{km} .)\end{array}$ & Comparatively, a small country in size $(110,372 \mathrm{sq} . \mathrm{km})$. \\
\hline Independence & 1947 & 1878 \\
\hline Physical Features & $\begin{array}{l}\text { A subcontinent with vast shoreline, } \\
\text { desert, vast Indo-Gangetic fertile land, } \\
\text { snowy Himalayan hill range in the } \\
\text { north, the south has Basalt rock } \\
\text { formations primarily. }\end{array}$ & $\begin{array}{l}\text { The territory falls into the Alpo-Himalayan Orogenic } \\
\text { Belt with diverse morphotectonic structures and relief, } \\
\text { with active modern tectonic processes. Complex } \\
\text { geological structure with a series of depressions, ravines } \\
\text { and terraces and the presence of water boundaries-the } \\
\text { Danube in the north and the Black Sea in east }\end{array}$ \\
\hline Elevation & $0-8586 \mathrm{~m}$ & 0-2925 m \\
\hline Disaster risk & $\begin{array}{l}\text { Landslides, Earthquakes, Floods, } \\
\text { Cyclones in Coastal Areas, }\end{array}$ & $\begin{array}{l}\text { Extreme Precipitation and Temperatures, Floods, } \\
\text { Earthquakes, Storms, Landslides, Wild-fires, Droughts }\end{array}$ \\
\hline
\end{tabular}


According to the INFORM Severity Index [59], which provides an objective measure for comparing the severity of humanitarian crises and disasters globally every month, India and Bulgaria have quite different indices. This index examines the impact of the crisis in terms of its geographical scope, human and physical effects, the conditions and status of the people affected and the complexity of the factors influencing its mitigation or resolution. For example, when considering disasters, India is the third most hazard-prone country globally, and it experiences various hazards that have caused considerable human and enormous economic losses in the past. Natural disasters such as earthquakes, floods, extreme temperatures and storms with pronounced spatial and temporal variability can cause human casualties and socio-economic damages. In the case of Bulgaria, disasters do not affect the country territory evenly. The more frequent disasters are floods, extreme temperatures, earthquakes, storms and wildfires.

For both countries, disaster events for the period 1990-2020 are presented in Figure 2 using data from the open-access EM-DAT roster [60]. The most common types of disasters in both countries are hydrological disasters, accounting for the largest share. These are followed by meteorological and geophysical disasters, with climate disasters accounting for the smallest share. The number of the same four main types of disasters for the last 60 years is shown in Figure 3. Despite the significant difference in the number of individual disastrous events in the two countries, there is a clear upward tendency to increase in recent decades, especially in adverse hydro-meteorological events. This increase in disasters addresses the socioeconomic dimensions such as population growth, urbanisation, economic activity and emerging climate change.

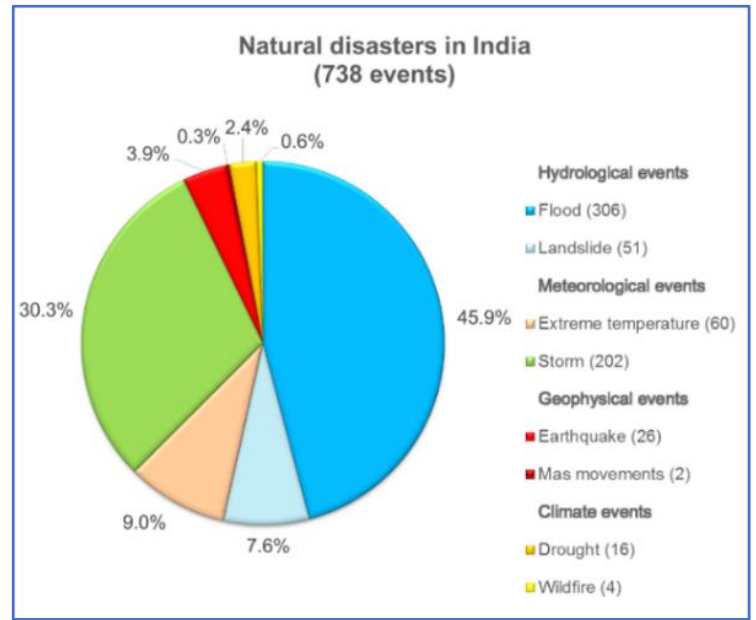

(a)

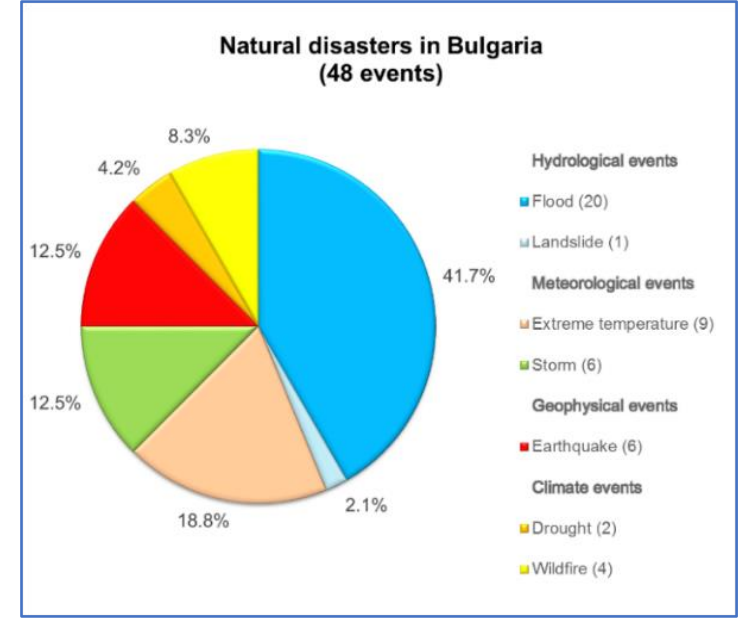

(b)

Figure 2. Comparison between the number of disasters in India (a) and Bulgaria (b) for the period 1900-2020 according to data from EM-DAT [60] (the number of relevant events is given in brackets) (accessed on 29 January 2021). 


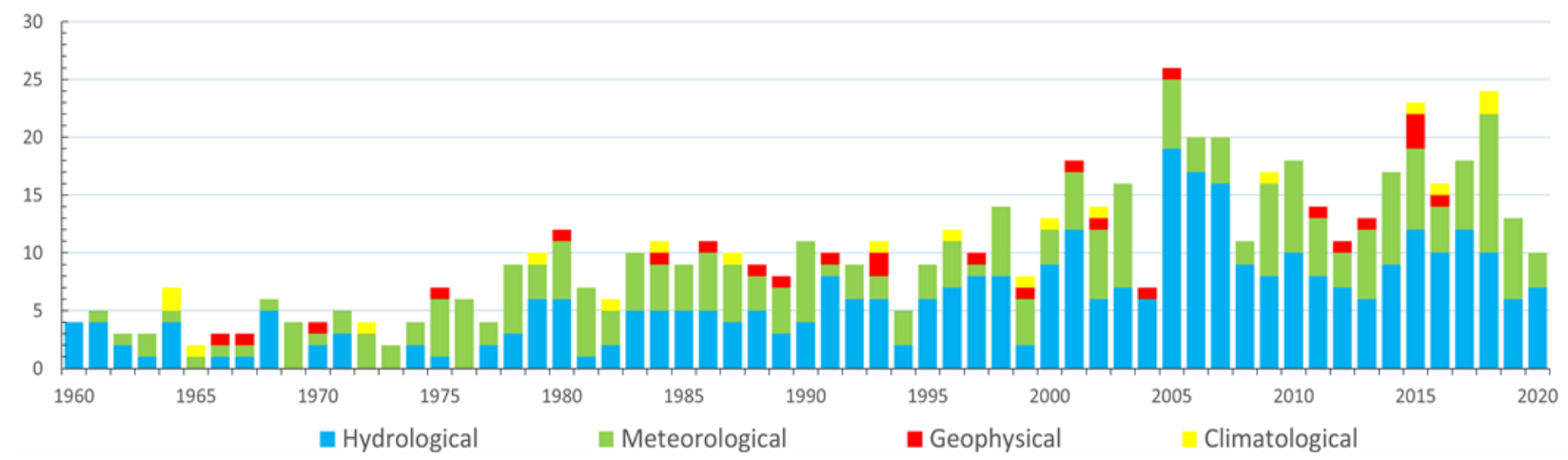

(a)

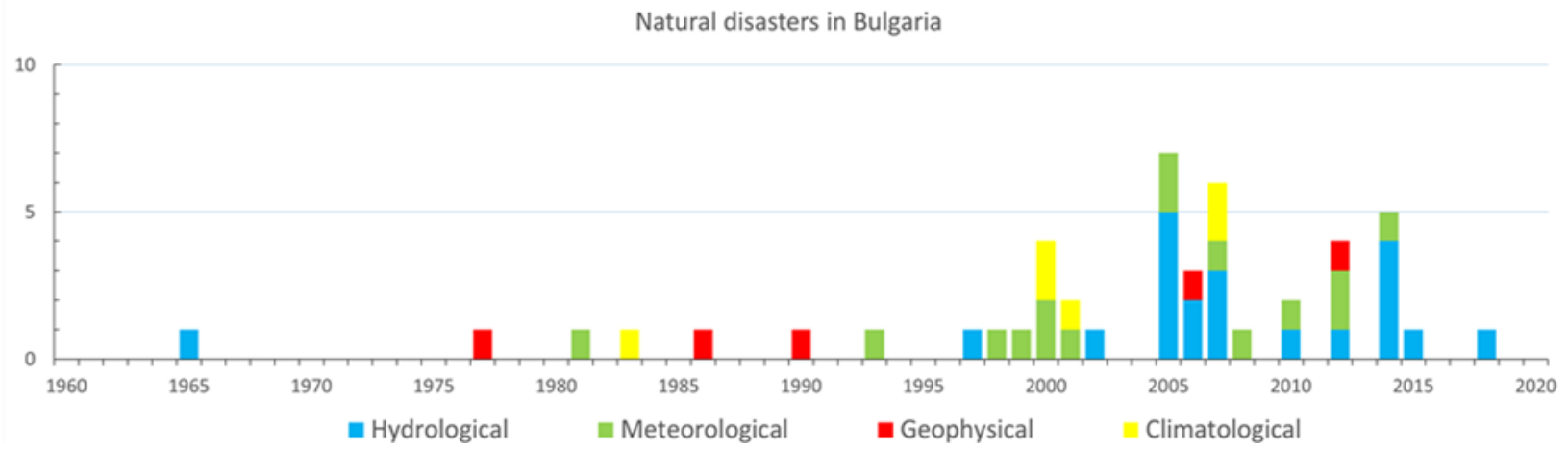

(b)

Figure 3. Disasters in India (a) and Bulgaria (b) for the period 1960-2020 (Data source: [60], accessed on 29 January 2021).

\section{Validation of the Criteria for the DRM Frameworks in India and Bulgaria}

As mentioned above, Sendai and UNGGIM are leading in developing national DRM frameworks. The process is very comprehensive and includes policymaking, development of appropriate strategies, plans and regulatory instruments at the national to the local level. In addition, practitioners on specific areas and issues have provided stakeholder guidance and recommendations in the national DRM organisational system. These national DRM documents are usually organised around three generic components: legal framework, policy and planning, and organisational arrangements. Therefore, the geospatial data criteria presented in Table 1 are verified for each of these three different components in comparing the national DRM frameworks of India and Bulgaria.

\subsection{Legal Base}

The comparison between the legal bases of both countries is summarised in Table 3 . As can be seen, the National Disaster Management Act 2005 of India is the umbrella act for the DRM mechanisms [61]. The Disaster Management Act 2005 does not explicitly discuss the geospatial aspects of or geospatial information for DRM. However, it serves as the legal basis for recommending policies and plans for DRM. India has no specific geospatial data law in the context of DRM. Some other Acts cover accidental hazards, but they too do not explicitly cover the geospatial data activities. The closest is the Environmental Protection Act [62], under which central government powers to take measures related to collection and dissemination of information in respect to environmental pollution or, after receiving information regarding excess discharge occurrence of an environmental pollutant due to some unforeseen event or accident, the agencies should take mitigation measures. Rules for Chemical Accidents 1996 [63] recommend setting up an information networking system with the state and district control rooms. The district crisis group ensures the continuous flow of information from the district to the central and state crisis groups on emergencies. It takes the necessary mitigation measures, disseminates information on chemical accident 
prevention, preparedness and mitigation in the country and the state, and to the local crisis group on the possible chemical accident at a site in the industrial pocket.

Table 3. Comparative geospatial data/information content according to the legal bases of India and Bulgaria.

\begin{tabular}{|c|c|c|}
\hline Activity/Criteria & $\begin{array}{l}\text { Intended/Existing } \\
\text { Laws/Legislation in India }\end{array}$ & $\begin{array}{l}\text { Intended/Existing Laws/Legislation } \\
\text { in Bulgaria }\end{array}$ \\
\hline 1. Existing data & - $\quad \mathrm{N} / \mathrm{A}^{*}$ & - Disaster Protection Act \\
\hline 2. Real-time data & - $\quad \mathrm{N} / \mathrm{A}$ & $\begin{array}{l}\text { - } \quad \text { Disaster Protection Act } \\
\text { Ordinances regulating the } \\
\text { requirements for protection in } \\
\text { case of disasters ** }\end{array}$ \\
\hline 3. Data management & - $\quad \mathrm{N} / \mathrm{A}$ & $\begin{array}{ll}\text { - } & \text { Disaster Protection Act } \\
\text { - } & \text { Law on Access to Spatial Data } \\
\end{array}$ \\
\hline 4. Capacity Building & - $\quad \mathrm{N} / \mathrm{A}$ & - Disaster Protection Act \\
\hline 5. Resource mobilisation & - $\quad \mathrm{N} / \mathrm{A}$ & - Disaster Protection Act \\
\hline
\end{tabular}

Bulgaria comes under European Union Regulations and Directives. Bulgarian legislation related to DRM/DRR is permanently updated following international and European Union (EU) requirements and standards in this field. The main European Union Acts in the field of DRR are Directive 96/82/EC on the control of significant accident hazards involving dangerous substances [64], Directive 2007/60/EC on the assessment and management of flood risks [65], Decision No 1313/2013/EU of the European Parliament and of the Council of 17 December 2013, on the Union Civil Protection Mechanism [66], and Directive 2008/114/EC on the identification and designation of critical European infrastructures and the assessment of the need to improve their protection [67]. The Disaster Protection Act [68] adopted in 2006 does not consider the spatial aspects of geospatial information for DRM. Disaster protection plans (DPP) are prepared based on the Disaster Protection Act 2006. The transposition of EU regulations in this area also requires commitments and related decisions at the national level. In 2012, an ordinance on the conditions, procedure and bodies for analysis, assessment and mapping of disaster risks was adopted and published in the State Gazette [69].

Regarding geospatial data, Bulgaria adopted in 2010 the Law on Access to Spatial Data [70], which transposed the provisions of the EU INSPIRE Directive [71] in the Bulgarian law. In addition to providing a basis for the interoperability of geospatial data in INSPIRE, the framework for the development of data specifications and thematic data specifications can be reused in other local, regional, national and global environments, contributing to improvements in incoherence and data interoperability in SDIs. Furthermore, disaster risk assessment, mitigation and management are closely tied with geospatial data compatibility, regulated in national law. However, some comparative analysis shows that legal, organisational and economic circumstances at different levels of government and available capacity hinder and negatively affect the activities undertaken to harmonise geographical information in Bulgaria in support of DRM/DRR policies (see, e.g., [72,73]).

Other normative acts of crucial importance in the management of the risk of natural and man-made hazards in various aspects are the Spatial Planning Act, Water Act, Environmental Protection Act, Nuclear Energy Safe Use Act, Health Act, Climate Change Limitation Act, Regional Development Act, Forestry Act, etc. Furthermore, the ongoing DRM policy is based on the guiding principles of the Sendai DRR Framework 2015-2030, such as cooperation, shared responsibility, coherence of sectoral policies, involvement of all in society and the involvement of all state institutions. In addition, the Republic of Bulgaria implements international cooperation in DRM through participation in the European Union 
Civil Protection Mechanism activities, and bilateral cooperation agreements concluded with neighbouring countries.

Table 3 shows that the Indian legal provisions do not cover geospatial data utilisation explicitly, although a few mentioned discussing the information collection and dissemination in the context of DRM. On the other hand, the legal provisions under the Disaster Protection Act in Bulgaria cover data collection, processing, quality and accuracy. In addition, the real-time data collection, forecasting, early warning and disaster assessment are partially regulated in by-laws, and as of July 2021, nine regulations are in force. For example, the Ordinance on Early Warning and Disaster Notification considers the procedure and the manner of their application by the executive bodies, the components of the Unified Rescue System of Bulgaria and the population rescue in case of disasters.

\subsection{Policy and Planning}

India launched a National Policy on Disaster Management 2009 (NPDM) and a National Disaster Management Plan (NDMP) 2016, revised in 2019. The NPDM 2009 underlined the vision of building a safe, resilient India by developing a holistic, proactive, multi-disaster-oriented and technology-driven strategy. It includes promoting the culture of prevention, preparedness and resilience, encouraging mitigation measures and developing new forecasting and early warning systems backed by responsive and fail-safe communication with information technology support. The themes underpinning the policy include community-based disaster management, consolidation of past initiatives and best practices and multi-sectorial synergy. The NDMP 2019 acts as an umbrella planning framework for disaster management in India. Its objectives include understanding disaster risk, strengthening disaster risk governance, investing in DRR for resilience and enhance disaster preparedness. The NDMP has the criteria of social inclusion as a crosscutting principle. In addition, the plan emphasises mainstreaming DRR into the overall development [74].

The lead policy document in Bulgaria on DRR/DRM is the DP Act [68] and the National Disaster Risk Reduction Strategy (NDRRS) 2014-2020 [75]. The strategy aims to identify the strategic priorities for DRR and support their implementation on national, district, municipal and specific subject levels. The National Strategy for DRR was updated in 2018, taking into account the international approach to ensure policy coherence for disaster risk reduction, climate change adaptation and sustainable development. The National DRR Program (NDRRP), 2021-2025, was adopted by Decision № 865 of the Council of Ministers at the end of 2020 [76]. The national program contains the strategic and operational goals and activities for their realisation. Simultaneously, sectoral legislation regulates requirements and procedures for coordination with the competent authorities, stakeholders and the public of documents related to assessing specific risks, including the conduct of a public hearing. Disaster management plans follow the NDRRP and address comprehensive and long-term DRR issues at the national and local levels, including risk management plans, disaster recovery and rehabilitation, and scientific and technical support.

Recently, in Bulgaria, some considerable improvement in the availability and conformity of the metadata and the spatial datasets has been achieved in the EU Directives implementation mentioned above [77]. Institutional and regulatory arrangements on DRM related data sharing, planning, and implementation of policies, agreements and codes among different institutions and organisations are in place and regulated by the DP Act [68]. A particular Theme 12-Natural risk zones (Annex III) of the INSPIRE Directive regulates the needed steps for improving interoperability, sharing and exchanging spatial data sets and services [78]. A new version of the National Concept for Spatial Development 20132025 was adopted in 2019, as the primary tool in developing the update of the concept is GIS with a structured geospatial database. The concept does not address the issues related to the geospatial data and geoinformation in detail and only mentions the National Strategy for Adaptation to Climate Change 2019 and the Action Plan until 2030, approved by the Council of Ministers of the Republic of Bulgaria with Decision $N^{\circ}$ 621/25.10.2019 [79]. An assessment of the DRM of nine sectors is provided in Appendix 10 of the Strategy, 
including a "costs-benefits analysis" from adaptation to climate change in selected sectors. Some general recommendations are mentioned, such as developing a specialised database on disaster risks, with visualisation in the GIS. In most national regulated documents, the climate change risks are not identified and addressed in sectorial legal and institutional arrangements. The practical use of the relevant geospatial data and information about the various stages of risk management is not regulated.

Standard features are established in the national activities, following good examples in the world practice when comparing the national DRM policies and plans in two countries. In both countries, hazard mapping activities are coordinated at the state level. In Bulgaria, the elaboration of maps of the danger and risk of disasters complies with the implementation of European directives, regulating requirements for the type and quality of data and information used in their preparation process. Several ministries participate in this process and coordinate separately the DRM activities depending on their responsibilities. Recently, many efforts have been made to use national and international resources and funding to develop national DRM/DRR legislation and put it into practice. However, due to insufficiently coordinated actions between all stakeholders in this area and the lack of established national spatial infrastructure [72,73], the Bulgarian national policy for dealing with disasters is still a challenge to be fully implemented.

The DRM policies and plans of both countries are examined and compared in Table 4 for comparison. This table shows that both countries plan to collect and process geospatial and statistical data to produce base maps, disaster-specific maps, observation networks and disaster loss area inventory. There is a typical level of understanding of the importance of dynamic information for DRM, reflected in collecting real-time data and generating forecasts, early warnings and disaster assessment. The products could be similar in both countries as real-time monitoring, early warnings, emergency communication network, meteorological observation systems and simulation to generate disaster scenarios. The activities of data management, sharing and dissemination are intended, which would require a designated data clearinghouse. A designated data gateway could make interoperability possible to share and disseminate the data among agencies as loss data. Management information systems of specific disaster types could also be a product of such data management activities. The aspect of inclusivity in DRM is encouraged through capacity building and public participation activities which involve acknowledging indigenous knowledge and research institutions contributions towards technical capacity. Knowledge management, applied research and training in chemical, biological, radiological and nuclear (CBRN) emergencies and geospatial technologies can be put under the category of specific products. The criterion of 'Resource Mobilisation' includes government agencies as nodal agencies and joint operation rooms. Contemporary technologies establishment and critical infrastructural assets resilience strengthening could be achieved through the activities of resource mobilisation. 
Table 4. Comparative geospatial data/information content between the DRM related policy and plans of India and Bulgaria.

\begin{tabular}{|c|c|c|}
\hline Activity/Criteria & Intended/Existing Products in India & Intended/Existing Products in Bulgaria \\
\hline 1. Existing data & $\begin{array}{l}\text { - } \quad \text { Base maps as land use, high-resolution } \\
\text { satellite images/ aerial photos integrated } \\
\text { with socioeconomic data. } \\
\text { - } \quad \text { Vulnerability atlas containing statistical } \\
\text { data and maps. } \\
\text { - } \quad \text { Disaster risk maps. } \\
\text { - } \quad \text { Disaster loss areas inventory. }\end{array}$ & $\begin{array}{l}\text { Observation networks and } \\
\text { stations-hydro-meteorological, seismic, strong } \\
\text { earth motion, GNSS, and others. } \\
\text { - } \quad \text { High-resolution satellite images/aerial photos. } \\
\text { - } \quad \text { Base maps as land use/land changes. } \\
\text { Disaster risk maps-seismic hazard, geological } \\
\text { hazard, flood hazard and risk, forest fires risk. } \\
\text { Disaster loss areas inventory. }\end{array}$ \\
\hline 2. Real-time data & $\begin{array}{l}\text { - } \quad \text { Real-time monitoring. } \\
\text { Multi-hazard early warnings and } \\
\text { information. } \\
\text { - National Emergency Communication } \\
\text { Network. } \\
\text { - } \quad \text { Meteorological observation systems. } \\
\text { Simulated scenarios for disaster events. }\end{array}$ & $\begin{array}{ll}\text { - } & \text { Real-time monitoring and alerting. } \\
\text { - } & \text { National early warning and notification system. } \\
\text { - } & \text { Hational Emergency Communication Network. } \\
\text { - } & \text { Seismic and strong earth motions systems. } \\
\text { - } & \text { Forest fires system. } \\
\text { - } & \text { Sea state systems. } \\
\text { - } & \text { Nuclear power plant alarm system. } \\
\text { - } & \text { Simulated scenarios for disaster events. }\end{array}$ \\
\hline $\begin{array}{l}\text { 3. Data } \\
\text { management }\end{array}$ & $\begin{array}{ll}\text { - } & \text { Loss data management. } \\
\text { - } & \text { Flood disaster management and } \\
\text { stormwater drainage systems. } \\
\text { - } \quad \text { Designated Data Clearinghouse. } \\
\text { Interoperable link between NSDI and } \\
\text { NDEC Network. }\end{array}$ & $\begin{array}{l}\text { - } \quad \text { Loss data management. } \\
\text { - } \text { management, seismic, geological and forest fires disaster } \\
\text { - Designated Data Clearinghouse. }\end{array}$ \\
\hline $\begin{array}{l}\text { 4. Capacity } \\
\text { Building }\end{array}$ & $\begin{array}{l}\text { - } \quad \text { Indigenous technical knowledge catalogue. } \\
\text { - } \& \text { T capacity development using technical } \\
\text { support from research institutions. } \\
\text { - } \quad \text { Kessons learnt from R\&D studies. } \\
\text { Knowledge management and applied } \\
\text { research and training in CBRN } \\
\text { emergencies. } \\
\text { Organising DRM focused training } \\
\text { programmes, including geospatial } \\
\text { technologies, for different stakeholders. }\end{array}$ & $\begin{array}{l}\text { - Technical knowledge guidelines and } \\
\text { educational/training materials. } \\
\text { - S\&T capacity development using technical support } \\
\text { from research institutions. } \\
\text { - } \quad \begin{array}{l}\text { European cooperation and mutual } \\
\text { assistance-joint training and exchange of } \\
\text { experience. }\end{array} \\
\text { - Lessons learnt from R\&D studies and 'good } \\
\text { practices. } \\
\text { Knowledge management and applied research and } \\
\text { - } \quad \text { Estaining in CBRN emergencies. } \\
\text { - Organising DRR dedicated events, conferences, } \\
\text { workshops, etc., especially with the participation of } \\
\text { all stakeholders. }\end{array}$ \\
\hline $\begin{array}{l}\text { 5. Resource } \\
\text { mobilisation }\end{array}$ & $\begin{array}{l}\text { - } \quad \text { Nodal agencies. } \\
\text { - Joint operation rooms connected planning } \\
\text { and execution systems. } \\
\text { Establishing and equipping with } \\
\text { contemporary technologies. } \\
\text { - Critical infrastructure resilience } \\
\text { strengthened. }\end{array}$ & $\begin{array}{l}\text { - } \quad \text { State agencies and responsible organisations. } \\
\text { - } \quad \text { execution systems. } \\
\text { Establishing and equipping contemporary } \\
\text { technologies. } \\
\text { - } \quad \text { Critical infrastructure resilience strengthened. } \\
\text { Targeted funding for the implementation of } \\
\text { national DRR programs and plans. }\end{array}$ \\
\hline
\end{tabular}

\subsection{Organisational Arrangements}

The organisational, institutional structure of India responsible for the DRM activities is presented in Figure 4. The Cabinet Committee on Security (CCS) performs incident evaluation from a national security perspective. The National Crisis Management Committee (NCMC) oversees the command, control and coordination of the disaster response and gives direction to the Management Authority (NDMA) to discharge its functions. This Committee is engaged in preparing the national plan, coordinating and monitoring the 
implementation of the national policy, and directing the relevant ministries or departments of the Government of India, the state governments and the state disaster management authorities (SDMAs) regarding response measures [74]. The Ministry of Home Affairs is the nodal ministry for national interventions for disaster risk management. In addition, there are central ministries designated as nodal Crisis Management Group and for specific actions of the central nodal ministries and is assisted by the National Executive Committee (NEC). NEC assists the National Disaster agencies for specific disasters; for example, the Ministry of Earth Sciences is responsible for monitoring earthquake activity. Under the same ministry, the Indian Meteorological Department (IMD) commonly provides rain and cyclone forecasting and assesses the occurrence of potential floods. The Central Water Commission (CWC), under the ministry related to water resources, provides flood warnings through its vast flood sensor network.

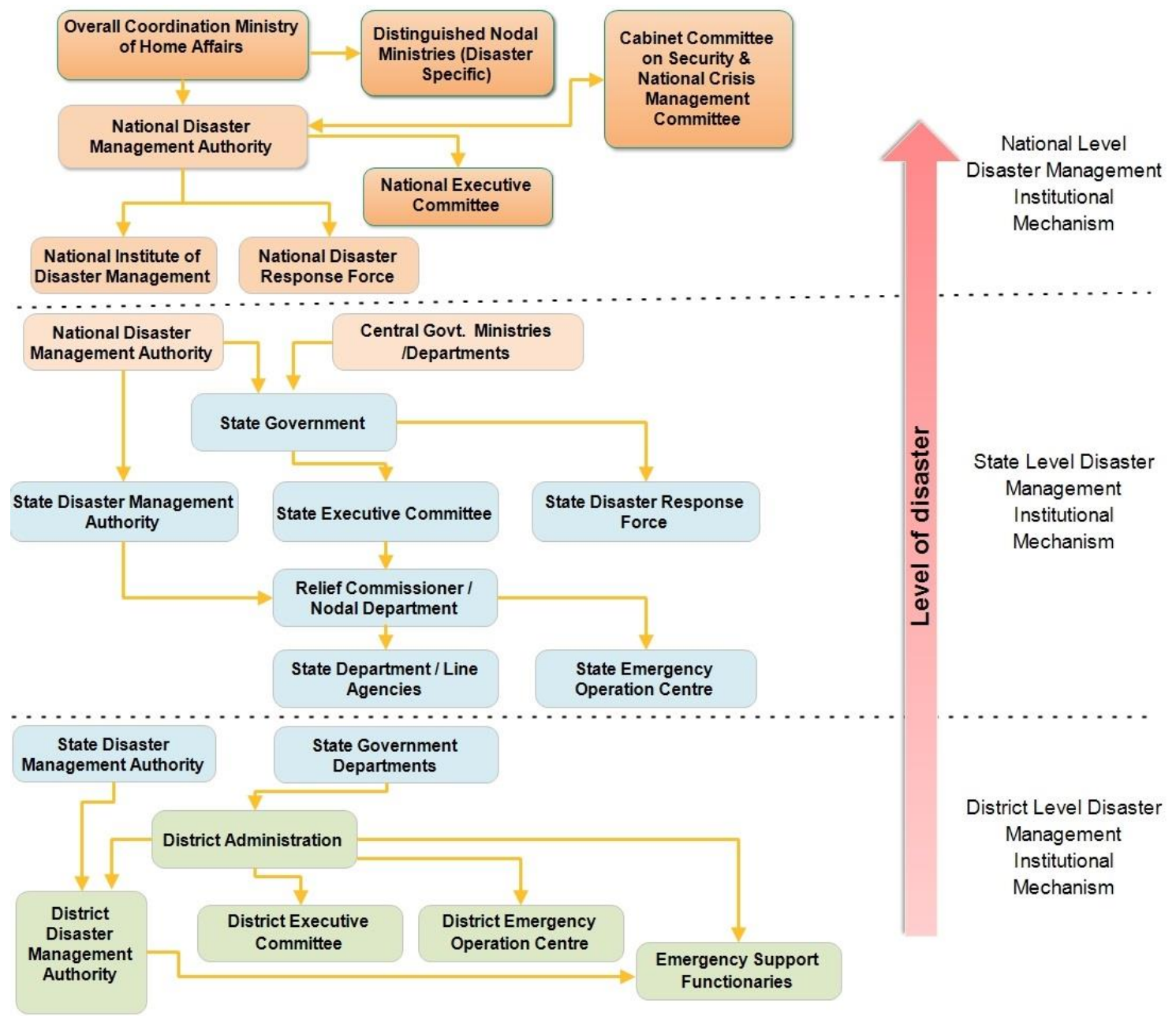

Figure 4. Organisational structure and responsible institutions for DRM in India. Partially sourced from NPDM, India [74] (accessed on 19 May 2021).

The NDMA lays down policies, plans and guidelines for disaster management to coordinate their enforcement and implementation throughout the country. It also approves the NDMP [74], and disaster management plans of the respective ministries and departments of the Government of India, and lays down guidelines for disaster management to be followed by different central ministries, departments and state governments. In addition, it has an Operations Division, which has the responsibility for liaising and coordinating with Early Warning Agencies. 
The National Institute for Disaster Management (NIDM) role is to coordinate the activities of the Human Resource Development and capacity building for disaster management within the broad policies and guidelines laid down by the NDMA. The National Disaster Response Force (NDRF) responds through trained human resources and specialised equipment. The armed forces assist the civil administration only when the situation is beyond their coping capacity. Para-military forces also play a crucial role in immediate response to disasters contributing to the NDRF. In addition, there are state disaster management bodies, state executive committees, state disaster response forces, a state control room for emergency operations and several departments. At the district level, there are regional bodies for disaster management with a centre for emergency operations in case of disasters. Then there are other local authorities involved as Emergency Support Functionaries (ESFs), including utility service providers, police, municipal and development authorities, etc. (see Figure 4) [74].

In addition, the municipal and development authorities have to set up their disaster management or hazard cells under the techno-legal regime provision of the DRM framework in India. Besides this, an Incident Response System (IRS) becomes active during the emergency, which involves different stakeholders from a district as ESFs. With a trigger event, IRS becomes active on a district level for the response. The Deputy Commissioner of the Revenue department leads the response efforts under the IRS as Incident Commander of the district. The Incident Commander takes over the authority to command the resources of other departments in the district for response purposes. In addition, international organisations such as the World Bank and UNDP are active in India. The UNDP is involved in many joint programs with the Indian government.

In Bulgaria, the DP Act [68] lists the competent authorities and their functions for DRM in all its phases-prevention, preparedness, response and recovery (see Figure 5). The law regulates the roles and responsibilities for disaster protection and guarantees coordination between the responsible institutions. They are ministries and organisations, district and municipal administrations, first aid centres, other medical and health-related bodies, legal entities and legal entities with limited responsibilities, voluntary formations and armed forces formations. Various governmental and non-governmental institutions, departments, offices and other operational structures carried out activities related to the civil protection in case of threat or disaster in Bulgaria [80]. These units, offices and other functional facilities are components of the Integrated Rescue System (IRS), while the institutional or organisational affiliation and their designated functions or objects are preserved. Civil protection expenditures are approximately $0.27 \%$ of the GDP [81]. The Interdepartmental Commission assists the Council of Ministers in providing earmarked funds from the state budget in connection with disasters. In case of emergencies that disaster has a significant or transboundary impact, international organisations can support civil and property protection activities based on specially signed agreements.

The population protection system of Bulgaria includes central and local executive bodies and organisations that manage, conduct and coordinate activities to protect the population and the national economy. The National Assembly in the country creates the legislation related to disasters, accidents and emergencies, and applies the general management in terms of state security and overcoming and mitigating the consequences. The preparation of the National DRP is an obligation of the DRR Council to the Council of Ministers. It includes representatives of ministries, departments, Bulgarian Academy of Sciences, universities, research institutes, the National Association of Municipalities, the Bulgarian Red Cross and legal entities, including non-profit legal entities, related to disaster risk reduction. The Council of Ministers established the Interdepartmental Commission for rehabilitation and assistance in Bulgaria in 2007. This Commission organises, coordinates and manages prevention activities at the national level. In disastrous events, it coordinates the interaction of the various ministries and departments and the implementation of the manoeuvre with the forces and resources of the territorial units assisted by the Crisis Centre. 
Heads or deputy heads of ministries and agencies related to state security and experts are members of the Commission [80,81].

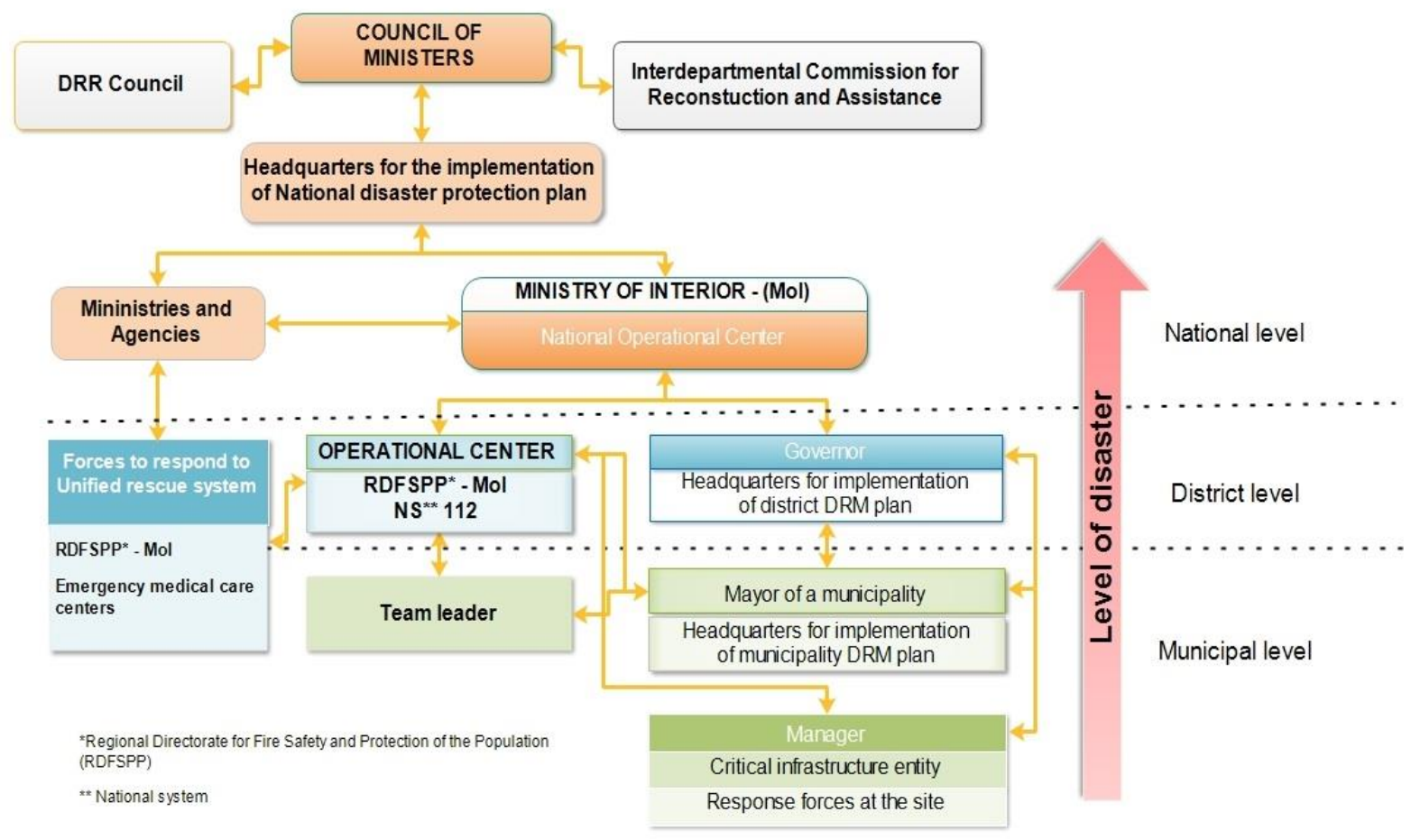

Figure 5. Organisational structure and responsible institutions for DRM in Bulgaria. Partially sourced from [81] (accessed on 25 April 2021).

The main components of the DRM system are the General Directorate "Fire Safety and Civil Protection" (GDFSCP) at the Ministry of Interior (MoI), the regional directorates at the same Ministry, the Bulgarian Red Cross (BRC) and the first aid centres. The Council of Ministers is the responsible body for authorising emergency costs in the event of disasters. The GDFSCP is the national body responsible for DRM, while district governors and mayors are primarily responsible for disaster protection at the district and municipal levels, respectively [80,81]. The GDFSCP at the MoI is a national specialised structure responsible for performing tasks related to prevention and preparedness, management, reaction and recovery in case of disasters. The Situation Centre of the GDFSCP at the MoI conducts the overall coordination in emergencies. Operational Communication and Information Centres in all 28 districts (regions) of the country also exist. The Red Cross has developed and implements a Policy and a Strategy for actions in disasters until 2020, which will be renewed according to the approved Strategy 2030 of the International Federation of Red Cross and Red Crescent Societies.

Comparing the organisational systems of India and Bulgaria, presented in Table 5, one can find closeness between them. For example, the respective organisations mandated with DRM in India maintain the inventory of disaster specific datasets. Similarly, in Bulgaria, statutory ministries, government agencies and research organisations maintain specific datasets related to disasters, with aggregated information subsequently provided to the National Statistical Institute, which exchanges it with European institutions. 
Table 5. Comparative geospatial data/information content of the organisational responsibilities of India and Bulgaria.

\begin{tabular}{|c|c|c|}
\hline Activity/Criteria & Intended/Existing Products in India & Intended/Existing Products in Bulgaria \\
\hline 1. Existing data & $\begin{array}{l}\text { Inventory of HVR descriptive } \\
\text { text, statistical data and maps. }\end{array}$ & $\begin{array}{l}\text { Inventory of the descriptive text of the HVR, statistics and } \\
\text { maps and their regular updating. } \\
\text { Verification of collected data with other sources of } \\
\text { information. } \\
\text { Providing real-time services for geospatial data concerning } \\
\text { disaster events. }\end{array}$ \\
\hline 2. Real-time data & $\begin{array}{l}\text { - } \quad \text { Disaster risk modelling. } \\
\text { Forecast maps, pre-warning } \\
\text { alerts, situation assessment } \\
\text { maps. }\end{array}$ & $\begin{array}{l}\text { - } \quad \text { Disaster hazard and risk evaluation. } \\
\text { - Disaster risk modelling and simulation. }\end{array}$ \\
\hline 3. Data management & $\begin{array}{l}\text { - Thematic Datasets shared. } \\
\text { Interoperable link between } \\
\text { NDMA and SDMAs. }\end{array}$ & $\begin{array}{l}\text { - Thematic data sets sharing, processing and analysis. } \\
\text { Interoperable links between research organisations, state } \\
\text { agencies and Ministries. }\end{array}$ \\
\hline 4. Capacity Building & $\begin{array}{l}\text { Theoretical and practical } \\
\text { geospatial education. } \\
\text { Training of stakeholders. }\end{array}$ & $\begin{array}{l}\text { - Theoretical and practical geospatial education. } \\
\text { - Joint training of stakeholders. }\end{array}$ \\
\hline $\begin{array}{l}\text { 5. Resource } \\
\text { mobilisation }\end{array}$ & $\begin{array}{l}\text { - Control rooms at national, state } \\
\text { and district levels. }\end{array}$ & $\begin{array}{l}\text { - National and European targeted funding. } \\
\text { - Development of national educational/training programs. }\end{array}$ \\
\hline
\end{tabular}

The dynamic datasets are helpful for near-real-time modelling outputs to forecast and pre-disaster warning alerts. These kinds of activities are done by specialised agencies, such as the Meteorological Department and the Central Water Commission in India under the Ministry of Earth Sciences and Ministry of Jal Shakti. These institutions provide services to show different stages of upcoming disasters such as cyclones, extreme meteorological events and floods. The Indian Space Research Organization (ISRO) provides satellite imageries based on current and previous trend situation assessment daily during a disaster event. In Bulgaria, research institutes or government agencies maintain dynamic data. For example, the National Institute of Meteorology and Hydrology provides real-time information on the weather, rivers and sea state, as well as their forecasting. The executive agency for exploration and maintenance of the Danube River performs functions following domestic and international law to implement international obligations of Bulgaria to manage, study and maintain conditions for navigation on the Danube. The National Institute of Geophysics, Geodesy and Geography at the Bulgarian Academy of Sciences provides real-time information about seismic activity, chemical weather, total ozone, Ultraviolet radiation, Earth magnetic field, geomagnetic activity and ionosphere status.

There are specific mechanisms, such as dedicated portals of respective organisations in India, that manage visualisation and basic query processing to share and disseminate thematic data sets. In addition to the satellite imagery-based dedicated portal 'Bhuvan' (https:/ /bhuvan.nrsc.gov.in/home/index.php; accessed on 19 May 2021) by the National Remote Sensing Agency of India, ISRO also provides base maps besides access to visualisation of thematic datasets (Geospatial and statistical) and analytic outputs for different disaster forecasts and warnings in the pre-disaster period (https:/ /bhuvan-app1.nrsc.gov.in/bhuvandisaster; accessed on 19 May 2021), acting as a facilitation point allows the users to select, browse and query the thematic datasets. Users can consume thematic datasets for integration as OGC Web Services into their systems.

In Bulgaria, some thematic datasets are available on the GIS website of the Ministry of Regional Development and Public Works on the following link http:/ / gis.mrrb. government.bg/ (accessed on 25 April 2021). At present, the National Methodology for hazard and risk flood mapping is under revision according to the EU Flood Directive, as the previous one was adopted in 2013 [82]. The four River Basin Directorates at the Min- 
istry of Environment and Water provide thematic maps on the hazard and risks of floods. In 2018, the National Institute of Geophysics, Geodesy and Geography at the Bulgarian Academy of Sciences developed a methodology for analysis, assessment and mapping of the seismic risk of Bulgaria [83]. The next step is developing a comprehensive seismic risk analysis, undertaken at the building and asset level, which is anticipated to provide a very high-level analysis of the extent of seismic risk, which will be finalised in 2025 . The Geological Institute at the Bulgarian Academy of Sciences elaborated a methodology for geological risk in 2014 [84]. The Nuclear Regulatory Agency is responsible for the nuclear and radiological emergency risks, but no mapping is available. Over the last decade, based on the nationally adopted methodologies, research organisations and local public bodies have compiled many hazard maps. In practice, the national territory threats are separately mapped, and multi-hazards are not taken into account.

Different institutions and organisations educate and qualify stakeholders to deal with risks and react and recover quickly in a disaster. In India, the National Institute of Disaster Management (NIDM) is the key agency mandated to train the stakeholders on the national level. It also includes workshops for training of trainers. The NDMA provides annual internships for working on various aspects of DRM. Technical institutions and universities are involved in capacity building through academic programmes, research studies and training workshops. The organisations in Bulgaria that deal with training, education and acquaintance of the population in emergencies are the GDFSCP at the MoI, the Bulgarian Red Cross and the executive authorities. The BRC works to increase the preparedness of the population for disaster response and, together with the civil protection bodies, prepares first aid units and provides such assistance. This institution provides humanitarian aid in case of natural and technological disasters, accidents, catastrophes/crises, etc. Disaster protection and first aid training are provided in schools and universities with technical support from representatives of nationally responsible organisations.

The resource mobilisation activities are comprehensive and overlapping with other activities and the resulting products. Control rooms are provided as an example for Indian DRM activities, which monitor, evaluate and respond according to the assessment of the situation in different phases of DRM. In the context of the geospatial data, resource mobilisation occurs by sharing the relevant datasets and their analysis results via interoperable links. The serious delays of Bulgaria in implementing the INSPIRE Directive and the National roadmap [73], and in particular the provision of services on the theme of 'Natural risk zones', are still a fact today. Some datasets on this theme are accessible through the national geoportal (https://inspire-catalogue.egov.bg/geonetwork/srv/eng/ catalog.search\#/home; accessed on 25 April 2021), and only a few of the 13 data concern the flood hazard and risk areas. Other activities related to the mobilisations of resources in Bulgaria include introducing mechanisms for ensuring the interconnection between the separate sectors through adequate measures for DRM in the territorial strategies for the country development and the plans for integrated development of the municipalities. By improving the understanding and adequate assessment of the impact of disasters on public finances, the aim is to stimulate insurance and other risk transfer mechanisms among the population and the private sector to accelerate disaster recovery. In both cases, this requires up-to-date data on potential natural hazards and risks assessment, as well as forecasts in the context of climate change, visualised on maps with the necessary spatial accuracy and details.

\section{Discussion}

This study investigated the references to geospatial data in DRM documents concerning the significant components: legal, policy, planning and organisational. These components lay the foundation of a national systemic response to the challenges posed by nature and anthropogenic activities. With legal backing and guidance provided by policy goals and visions, the designated agencies are mandated to collect, maintain, share and disseminate geospatial information. The geospatial data activities considered under these 
components cover the entire spectrum of DRM interventions at various stages to prevent and reduce the risk, prepare for and respond to the hazard events, and finally recover from the disaster event loss. These activities arguably should be used as criteria for the comparison of DRM frameworks.

Comparing the national DRM frameworks for the two use cases, applying the geospatial data activities as criteria reveals the technology-based approach commonality. Particular attention is given to the effective use of geospatial information as feedback is sought from all stakeholders in the DRM process. Table 3 shows that the legal components related to DRM in Bulgaria cover the entire chain of geospatial data collection, utilisation, dissemination and analysis, which is to some extent determined by the country membership in the European Union. In the last decade, significant changes have occurred, but there is still some lag in establishing national spatial infrastructure and access to geospatial data needed for DRM/DRR. Similar legislation documents are existing in India; however, they do not address the geospatial data explicitly. The intentions expressed at the governance level through the policy and planning measures listed in Table 4 show that India and Bulgaria are acting and striving for a responsible national policy in disaster prevention. In both countries, different measures have been taken at different levels of government to improve the collection and processing of geospatial and statistical data, as well as their access, sharing and dissemination for DRM purposes. According to the selected criteria in Table 5, it is evident that these intentions are carried further to the organisational level for implementation.

As can be observed under the criterion 1. Existing data, a large variety of products have been mentioned, which categorically clarifies that the two nations recognise the geospatial and statistical data importance for DRM activities. The pre-disaster efforts in the form of maps, alerts, forecasts and simulations give an idea of the potential impact or intensity before the actual disaster event and reduce the risk essentially. The criterion 2. Real-time data is also very prominent. Scenario-specific models, forecast maps, prewarning alerts, situation assessment maps, real-time disaster hazard and risk evaluation and simulation are the activities mentioned in the DRM framework. Criterion 3. Data management allows the comparison of approaches for the management and dissemination of geospatial data. The documents of both countries emphasise that analytic outputs need to be provided in a standardised way for harmonising the process of information shared and made accessible with the targeted stakeholders. A designated data clearinghouse as a part of the data management operations is envisaged to handle data. The communication with the stakeholders to be maintained at all stages of DRM is to be achieved through inclusive, participatory methods and acknowledging the information from different knowledge sources. The two criteria 4. Capacity building and 5. Resource management reflect the efforts for preparation and mobilising of resources in anticipation. The two countries have listed initiatives to increase the preparedness of the population and public participation in the disaster management cycle and optimise the resources needed at different levels of government to build capacity to deal with emergencies.

The study has clearly shown that the policy documents reflect many geospatial aspects, and several documents have been developed as recommendations and mandated through the national-level frameworks in India and Bulgaria. Therefore, the comparative result provides a positive case to promote the derived geospatial criteria as a general recommendation for the comparative evaluation of national DRM frameworks. Based on this understanding, in its final part, the paper provides an inference and recommendations for adopting the derived geospatial criteria in other countries.

\section{Conclusions}

The increased frequency of disasters and their severity has prompted nations to meet these challenges by creating their DRM frameworks tailored to their specific manifestations in a given area. Geospatial technologies are the common denominator in disaster prevention responses. As they progress, these advanced technologies play an increasing role in 
the DRM process. Different aspects of geospatial data activities from the data collection, management, modelling to capacity building and resource mobilisation are revealed as the elements focused on the priorities of the Sendai and UNGGIM multilateral frameworks. These elements are used as a set of criteria for comparative analysis of the DRM frameworks of India and Bulgaria, i.e., two countries with significant differences in geographical, social, economic and policy aspects. The analysis results reveal many similarities regarding the geospatial data utilisation for various purposes under the DRM framework. Therefore, we recommend that the criteria derived and verified through use cases in this paper are appropriate and comprehensive. Moreover, it is determined from multilateral internationally accepted DRM frameworks, which gives it a basis for wide-ranging acceptance and could be used as a generic evaluation set of criteria for the geospatial data consideration given under the specific components of a DRM framework.

Author Contributions: Conceptualization, Tarun Ghawana and Lyubka Pashova; methodology, Tarun Ghawana, Lyubka Pashova and Sisi Zlatanova; writing-original draft preparation, Tarun Ghawana and Lyubka Pashova; writing — review and editing, Tarun Ghawana, Lyubka Pashova and Sisi Zlatanova; visualization, Tarun Ghawana and Lyubka Pashova. All authors have read and agreed to the published version of the manuscript.

Funding: This research received no external funding.

Data Availability Statement: The data used in the present study are publicly available on the website of EM-DAT Database, http:/ / www.emdat.be/.

Acknowledgments: The authors express their gratitude to the anonymous reviewers for improving the quality of this article.

Conflicts of Interest: The authors declare no conflict of interest.

\section{References}

1. ECLAC \& WB. Handbook for Estimating the Socioeconomic and Environmental Effects of Disasters. In Economic Commission for Latin America and the Caribbean; United Nations Economic Commission for Latin America and the Caribbean: Santiago, Chile, 2003; 357p. Available online: https:/ / reliefweb.int/report/world/handbook-estimating-socio-economic-and-environmentaleffects-disasters (accessed on 25 August 2020).

2. UNISDR. Global Assessment Report on Disaster Risk Reduction; United Nations International Strategy for Disaster Reduction: Geneva, Switzerland, 2015; 316p. Available online: https:/ / www.undrr.org/publication/global-assessment-report-disaster-riskreduction-2015 (accessed on 12 August 2020).

3. UNDRR. Global Assessment Report on Disaster Risk Reduction; United Nations Office for Disaster Risk Reduction: Geneva, Switzerland, 2019; 425p. Available online: https: / /gar.unisdr.org (accessed on 15 August 2020).

4. NPDM. National Policy on Disaster Management; Ministry of Home Affairs: New Delhi, India, 2009. Available online: https: //nidm.gov.in/PDF/policies/ndm_policy2009.pdf (accessed on 25 August 2020).

5. National Response Framework, 4th ed.; Homeland Security: Washington, DC, USA, 2019; 57p. Available online: https://www.fema. gov/sites/default/files/2020-04/NRF_FINALApproved_2011028.pdf (accessed on 5 August 2021).

6. Marx, S.; Barbeito, G.; Fleming, K.; Petrovic, B.; Pickl, S.; Thieken, A.; Zeidler, M. Synthesis Report on Disaster Risk Reduction and Climate Change Adaptation in Germany. In DKKV-Schriftenreihe, Enhancing Synergies for Disaster Prevention in the European Union; German Committee for Disaster Reduction Enhancing Synergies for disaster Prevention in the EurOpean Union: Bonn, Germany, 2017; 76p, ISBN 978-3-00-058657-6.

7. IFRC. Legal Preparedness for Regional and International Disaster Assistance in the Pacific. Country Profiles; International Federation of Red Cross and Red Crescent Societies: Geneva, Switzerland, 2020; 118p. Available online: https://www.preventionweb.net/ files/73794_idrlinpacificcountryprofileslr.pdf (accessed on 11 November 2020).

8. Molina, M.; Bayarri, S. A multinational SDI-based system to facilitate disaster risk management in the Andean Community. Comput. Geosci. 2011, 37, 1501-1510. [CrossRef]

9. EUSTAG. Socioeconomic and Data Challenges Disaster Risk Reduction in Europe; Sparf, J., Migliorini, M., Eds.; EU Science \& Technology Advisory Group: Brussels, Belgium, 2019;33p. Available online: https://www.preventionweb.net/publications/view/65182 (accessed on 11 March 2021).

10. UNISDR. Sendai Framework for Disaster Risk Reduction 2015-2030; United Nations Office for Disaster Risk Reduction: Geneva, Switzerland, 2015.

11. UNGGIM. UN Strategic Framework on Geospatial Information and Services for Disasters, 2017. Available online: https: //ggim.un.org/documents/UN-GGIM_Strategic_Framework_Disasters_final.pdf (accessed on 15 December 2020). 
12. Tomaszewski, B.M.; Moore, E.A.; Parnell, K.M.; Leader, A.; Armington, W.R.; Aponte, O.; Brooks, L.; Herold, B.K.; Meyers, B.S.; Ruggero, T.; et al. Developing a geographic information capacity (GIC) profile for disaster risk management under United Nations framework commitments. Int. J. Disaster Risk Reduct. 2020, 47, 101638. [CrossRef]

13. Manfré, L.A.; Hirata, E.; Silva, J.B.; Shinohara, E.J.; Giannotti, M.A.; Larocca, A.P.C.; Quintanilha, J.A. An Analysis of Geospatial Technologies for Risk and Natural Disaster Management. ISPRS Int. J. Geo-Inf. 2012, 1, 166-185. [CrossRef]

14. Fekete, A.; Tzavella, K.; Armas, I.; Binner, J.; Garschagen, M.; Giupponi, C.; Serre, D. Critical Data Source; Tool or Even Infrastructure? Challenges of Geographic Information Systems and Remote Sensing for Disaster Risk Governance. ISPRS Int. J. Geo-Inf. 2015, 4, 1848-1869. [CrossRef]

15. Zlatanova, S.; van Oosterom, P.; Verbree, E. Geo-information supports management of urban disasters. Open House Int. 2006, 31, 62-79. [CrossRef]

16. Nayak, S.; Zlatanova, S. (Eds.) Remote Sensing and GIS Technologies for Monitoring and Prediction of Disasters; Springer-Verlag: Berlin/Heidelberg, Germany, 2008; 271p.

17. Kerle, N.; Heuel, S.; Peifer, N. Real-time data collection and information generation using airborne sensors. In Geospatial Technology for Emergency Response; Li, J., Zlatanova, S., Eds.; CRC Press: Boca Raton, FL, USA, 2008; pp. 43-74.

18. Zhang, Y.; Kerle, N. Satellite and remote sensing for near-real time data collection. In Geospatial Technology for Emergency Response; Li, J., Zlatanova, S., Eds.; CRC Press: Boca Raton, FL, USA, 2008; pp. 75-102.

19. Li, J.; Chapman, M.A. Terrestrial mobile mapping towards real-time geospatial data collection. In Geospatial Technology for Emergency Response; Li, J., Zlatanova, S., Eds.; CRC Press: Boca Raton, FL, USA, 2008; pp. 103-122.

20. Mansourian, A.; Rajabifard, A.; Zoej, M.J.V. Development of a Web-Based GIS Using SDI for Disaster Management. In Geoinformation for Disaster Management; van Oosterom, P., Zlatanova, S., Fendel, E.M., Eds.; Springer: Berlin/Heidelberg, Germany, 2005. [CrossRef]

21. Koswatte, S.; McDougall, K.; Liu, X. SDI and crowdsourced spatial information management automation for disaster management. Surv. Rev. 2015, 47, 307-315. [CrossRef]

22. Xie, J.; Li, G. Distributed geospatial data infrastructure for heterogeneous disaster data integration and application. In 2017 IEEE SmartWorld, Ubiquitous Intelligence \& Computing, Advanced \& Trusted Computed, Scalable Computing E Communications, Cloud E Big Data Computing; Internet of People and Smart City Innovation (SmartWorld/SCALCOM/UIC/ATC/CBDCom/IOP/SCI): San Francisco, CA, USA, 2017; pp. 1-4. [CrossRef]

23. Sterlacchini, S.; Bordogna, G.; Cappellini, G.; Voltolina, D. SIRENE: A Spatial Data Infrastructure to Enhance Communities' Resilience to Disaster-Related Emergency. Int. J. Disaster Risk Sci. 2018, 9, 129-142. [CrossRef]

24. Barbero, M.; Lopez, P.M.; Vancauwenberghe, G.; Vandenbroucke, D. The Role of Spatial Data Infrastructures in the Digital Government Transformation of Public Administrations; Publications Office of the European Union: Luxembourg, 2019.

25. He, Z.; Liu, G.; Ma, X.; Chen, Q. GeoBeam: A distributed computing framework for spatial data. Comput. Geosci. 2019, 131, 15-22. [CrossRef]

26. Zlatanova, S.; Fabbri, A.G. Geo-ICT for risk and disaster management. In Geospatial Technology and the Role of the Location in Science; Scholten, H.J., Velde, R., van Manen, N., Eds.; Springer: Berlin/Heidelberg, Germany, 2009; pp. 239-266.

27. Scholten, H.; Fruijter, S.; Dilo, A.; van Borkulo, E. Spatial Data Infrastructure for Emergency Response in Netherlands. In Remote Sensing and GIS Technologies for Monitoring and Prediction of Disasters. Environmental Science and Engineering (Environmental Science); Nayak, S., Zlatanova, S., Eds.; Springer: Berlin/Heidelberg, Germany, 2008. [CrossRef]

28. Bandrova, T.; Zlatanova, S.; Konecny, M. Three-dimensional maps for disaster management. ISPRS Ann. Photogramm. Remote Sens. Spatial. Inf. Sci. 2012, I-4, 245-250. [CrossRef]

29. Bhanumurthy, V.; Rao, R.M.K.; Sankar, J.G.; Nagamani, P.V. Spatial data integration for disaster/emergency management: An Indian experience. Spat. Inf. Res. 2017, 25, 303-314. [CrossRef]

30. Konecny, M.; Zlatanova, S.T.; Bandrova, T. Geographic Information and Cartography for Risk and Crisis Management: Towards Better Solutions; Springer: Berlin/Heidelberg, Germany, 2010; 446p.

31. Kozel, J.; Štampach, R. Practical experience with a contextual map service. In Lecture Notes in Geographic Information and Cartography for Risk and Crisis Management: Towards Better Solutions; Konecny, M., Zlatanova, S., Bandrova, T., Eds.; Springer: Berlin/Heidelberg, Germany, 2010; pp. 305-316. [CrossRef]

32. Fan, Z.; Zlatanova, S. Exploring ontology potential in emergency management. In Proceedings of the Gi4DM ConferenceGeomatics for Disaster Management, Torino, Italy, 2-4 February 2010. Available online: http://repository.tudelft.nl/view/ir/ uuid:135e1c0c-b2e0-453c-bc3a-64c9e1955901/ (accessed on 20 December 2020).

33. Dilo, A.; Zlatanova, S. A data model for operational and situational information in emergency response. Appl. Geomat. 2011, 3, 207-218. [CrossRef]

34. Moreira, J.; Pires, L.F.; van Sinderen, M.J.; Costa, P.D. Towards ontology-driven situation-aware disaster management. Appl. Ontol. 2015, 10, 339-353. [CrossRef]

35. Zlatanova, S. SII for Emergency Response: The 3D Challenges. In Proceedings of the XXI ISPRS Congress, Part B4-TYC IV, Beijing, China, 3-11 July 2008; Jiang, C., Nayak, S., Eds.; pp. 1631-1637. Available online: https:/ / ocw.tudelft.nl/wp-content/uploads/ Emergency_Response_and_3D.pdf (accessed on 29 January 2021). 
36. Altan, O.; Backhaus, R.; Boccardo, P.; van Manen, N.; Trinder, J.; Zlatanova, S. The Value of Geoinformation for Disaster and Risk Management (VALID): Benefit Analysis and Stakeholder Assessment; JB GIS: Copenhagen, Denmark, 2013; 130p, ISBN 987-87-9090788-4. Available online: https://www.preventionweb.net/publications/view/34805 (accessed on 29 January 2021).

37. Scott, G.; Rajabifard, A. Sustainable development and geospatial information: A strategic framework for integrating a global policy agenda into national geospatial capabilities. Geo Spat. Inf. Sci. 2017, 20, 59-76. [CrossRef]

38. Ghawana, T.; Zlatanova, S. Institutional Arrangements and Spatial Information Initiatives for Disaster Management in International Organisations: Compendium; Coordinates Media Pvt Ltd.: Delhi, India, 2018; ISBN 978-81-908172-2-6.

39. Surianto, S.; Alim, S.; Nindrea, R.D.; Trisnantoro, L. Regional Policy for Disaster Risk Management in Developing Countries within the Sendai Framework: A Systematic Review. Open Access Maced. J. Med Sci. 2019, 7, 2213-2219. [CrossRef] [PubMed]

40. Gupta, A.K. Disaster Governance and Legal Systems in India. In Disaster Risk Governance in India and Cross Cutting Issues, Disaster Risk Reduction (Methods, Approaches and Practices); Pal, I., Shaw, R., Eds.; Springer: Singapore, 2018; pp. 39-60. [CrossRef]

41. Jones, S.; Joven, K.; Manyena, B.; Aryal, K. Governance struggles and policy processes in disaster risk reduction: A case study from Nepal. Geoforum 2014, 57, 78-90. [CrossRef]

42. Bhandari, D.; Neupane, S.; Hayes, P.; Regmi, B.; Marker, P. Disaster Risk Reduction and Management in Nepal: Delineation of Roles and Responsibilities; Oxford Policy Management: Oxford, UK, 2020; 76p. Available online: https://www.preventionweb.net/ publications/view/72985 (accessed on 5 August 2020).

43. Aronsson-Storrier, M. Sendai Five Years on: Reflections on the Role of International Law in the Creation and Reduction of Disaster Risk. Int. J. Disaster Risk Sci. 2020, 11, 230-238. [CrossRef]

44. Greiving, S.; Schödl, L.; Gaudry, K.H.; Miralles, I.K.Q.; Larraín, B.P.; Fleischhauer, M.; Guerra, M.M.J.; Tobar, J. Multi-Risk Assessment and Management-A Comparative Study of the Current State of Affairs in Chile and Ecuador. Sustainability 2021, 3 , 1366. [CrossRef]

45. Maria, A.; Lendvai, G. Comparative analysis of disaster risk management practices in Bucharest, Ciudad de Mexico and Istanbul. GeoPatterns 2019, 4, 16-25. [CrossRef]

46. Banerji, P.; Singh, N. Comparative Analysis of Disaster Management between Japan \& India. IOSR J. Bus. Manag. 2013, 13, 62-74.

47. Fernandez, J.; Bendimerad, F.; Mattingly, S.; Buika, J. Comparative Analysis of Disaster Risk Management Practices in Seven Megacities. In Proceedings of the 2nd Asian Conference on Earthquake Engineering, Manila, Philippines, 10-11 March 2006; p. 21. Available online: https:/ / www.alnap.org/help-library / comparative-analysis-of-disaster-risk-management-practices-inseven-megacities (accessed on 5 August 2021).

48. Lestari, T.Y.; Rachman, R.; Syamsuddin, A.S.P. Comparative Analysis of Disaster Management Between Indonesia and Japan from Regulatory and Institutional Aspects; International Conference on Urban Disaster Resilience. MATEC Web Conf. 2020, 331, 01007. [CrossRef]

49. Mansor, S.; Abu Shariah, M.; Billa, L.; Setiawan, I.; Jabar, F.; Mansor, S.; Abu Shariah, M.; Billa, L.; Setiawan, I.; Jabar, F. Spatial technology for natural risk management. Disaster Prev. Manag. 2004, 13, 364-373. [CrossRef]

50. Stefansson, R. Useful predictions ahead of large earthquakes and lessons learned for future progress. Geod. Geodyn. 2020, 11, 1-17. [CrossRef]

51. UNCTAD. Geospatial Science and Technology For development: With a Focus on Urban Development, Land Administration and Disaster Risk Management; United Nations: Geneva, Switzerland, 2012.

52. UN-FAO Spatial Technology in Disaster Risk Management. In Guidance on Spatial Technologies for Disaster Risk Management in Aquaculture-A Handbook; Manzarrez, J.A.; Wickliffe, L.C.; Dean, A. (Eds.) UN-FAO: Rome, Italy, 2018; p. 120.

53. Khamespanah, F.; Delavar, M.R.; Moradi, M.; Sheikhian, H. A GIS-based multi-criteria evaluation framework for uncertainty reduction in earthquake disaster management using granular computing. Geod. Cartogr. 2016, 42, 58-68. [CrossRef]

54. OGC REPORT: OGC Development of Disaster Spatial Data Infrastructures for Disaster Resilience. In OGC Disasters Interoperability Concept Development Study; Idol, T.; Thomas, R. (Eds.) OGC: Welland, MA, USA, 2018.

55. Mansourian, A.; Rajabifard, A.; Zoej, M.J.V.; Williamson, I. Using SDI and web-based system to facilitate disaster management. Comput. Geosci. 2006, 32, 303-315. [CrossRef]

56. Abbas, S.H.; Srivastava, R.K.; Tiwari, R.P.; Ramudu, P.B. GIS-based disaster management; A case study for Allahabad Sadar sub-district (India). Manag. Environ. Qual. 2009, 20, 33-51. [CrossRef]

57. Bhanumurthy, V.; Sharma, V.K. Integration of multiple technologies in web environment for developing an efficient framework for emergency management. In Proceedings of International Conference on Remote Sensing for Disaster Management, Issues and Challenges in Disaster Management 2019; Rao, J.P., Rao, K.N., Kubo, S., Eds.; Springer: Cham, Switzerland, 2019. [CrossRef]

58. Ran, J.; Budic, Z.N. Integrating spatial planning and flood risk management: A new conceptual framework for the spatially integrated policy infrastructure. Comput. Environ. Urban. Syst. 2016, 57, 68-79. [CrossRef]

59. INFORM Severity Index-2020. Available online: https://drmkc.jrc.ec.europa.eu/inform-index/INFORM-Severity (accessed on 5 November 2020).

60. EM-DAT. CRED/UCLouvain, Brussels, Belgium (D. Guha-Sapir), 2020. Available online: https://www.emdat.be/ (accessed on 7 November 2020).

61. National Disaster Management Act 2005, India, 2005. Available online: https://cdn.s3waas.gov.in/s365658fde58ab3c2b6e5132a3 9fae7cb9/uploads/2018/04/2018041720.pdf (accessed on 15 January 2021). 
62. EPA, Section 3 and 9; The Environment (Protection) Act 1986, India. Available online: https://www.indiacode.nic.in/bitstream/ 123456789/6196/1/the_environment_protection_act\%2C1986.pdf (accessed on 17 October 2020).

63. CA Rules, Section 4, 9 and 13, Chemical Accident (Emergency Planning, Preparedness and Response) Rules, 1996. Available online: https://labour.uk.gov.in/files/THE_CHEMICAL_ACCIDENTS_(EMERGENCY_PLANNING,_PREPAREDNESS,.pdf (accessed on 17 October 2020).

64. EC. Directive 96/82/EC on the Control of Major Accident Hazards Involving Dangerous Substances, OJ L 10, 14.1.1997, 13-33. Available online: https:/ / eur-lex.europa.eu/legal-content/en/ALL/?uri=CELEX\%3A31996L0082 (accessed on 15 November 2020).

65. EC. Directive 2007/60/EC of the European Parliament and of the Council of 23 October 2007 on the Assessment and Management of Flood Risks (Text with EEA relevance) OJ L 288, 6.11.2007, 27-34. Available online: https:/ / eur-lex.europa.eu/legal-content/ $\mathrm{EN} / \mathrm{TXT} /$ ?uri=celex:32007L0060 (accessed on 15 January 2021).

66. EC. Decision No 1313/2013/EU of the European Parliament and of the Council of 17 December 2013 on a Union Civil Protection Mechanism Text with EEA relevance OJ L 347, 20.12.2013, 924-947. Available online: https:/ / eur-lex.europa.eu/legal-content/ $\mathrm{EN} / \mathrm{TXT} /$ ? uri=celex\%3A32013D1313 (accessed on 16 January 2021).

67. EC. Directive 2008/114/EC on the Identification and Designation of European Critical Infrastructures and the Assessment of the Need to Improve Their Protection, OJ L 345, 23.12.2008, 75-82. Available online: https:/ / eur-lex.europa.eu/legal-content/en/ ALL/?uri=CELEX:32008L0114 (accessed on 16 January 2021).

68. State Gazette, N102, 2006, Disaster Protection Act, N-Lex. Available online: http:/ / fao.org/faolex/results/details/en/c/LEXFAOC116425/ (accessed on 15 November 2020).

69. State Gazette, N84, 2012, Ordinance on the Conditions, Procedure and Bodies for Performing Analysis, Assessment and Mapping of Disaster Risks. Available online: https:/ / www.lex.bg/laws/ldoc/2135819583 (accessed on 15 November 2020). (In Bulgarian)

70. State Gazette, N19, 2010, Law on Access to Spatial Data, N-Lex. Available online: http://eur-lex.europa.eu/n-lex/legis_bg/ index_bg (accessed on 15 November 2020).

71. EC. Commission of the European Communities, Directive 2007/2/EC of the European Parliament and of the Council of 14 March 2007 Establishing an Infrastructure for Spatial Information in the European Community (INSPIRE). Off. J. Eur. Union 2007, L108, 1-14. Available online: http:/ / eur-lex.europa.eu/legal-content/EN/TXT/?uri=OJ (accessed on 15 November 2020).

72. Pashova, L.; Kouteva-Guentcheva, M.; Bandrova, T. Towards Mapping Multi-Hazard Vulnerability of Natural Disasters for the Bulgarian Territory. In Proceedings of the 6th International Conference on Cartography and GIS, Albena, Bulgaria, 13-17 June 2016; Bandrova, T., Konecny, M., Eds.; Bulgarian Cartographic Association: Sofia, Bulgaria. Available online: https: / / cartography-gis.com/docsbca/iccgis2016/ICCGIS2016-85.pdf (accessed on 12 November 2020).

73. Pashova, L.; Bandrova, T. A brief overview of current status of European spatial data infrastructures-relevant developments and perspectives for Bulgaria. Geo Spat. Inf. Sci. 2017, 20, 97-108. [CrossRef]

74. NDMP. 1.14 Institutional Framework 2019. Available online: https://ndma.gov.in/sites/default/files/PDF/ndmp-2019.pdf (accessed on 15 September 2020).

75. National Disaster Risk Reduction Strategy 2018-2030, 2018. Available online: http:/ /www.strategy.bg/StrategicDocuments/ View.aspx?lang=bg-BG\&Id=1279, (accessed on 15 August 2020).

76. National Disaster Risk Reduction Program 2021-2025, 2020. Available online: https://saveti.government.bg/c/document_ library / get_file?p_1_id=104762\&folderId=1606938\&name=DLFE-9240.pdf (accessed on 15 June 2021).

77. INSPIRE in your Country: Bulgaria. 2020. Available online: https:/ /inspire.ec.europa.eu/country-fiche/bulgaria-2020-countryfiche (accessed on 21 December 2020).

78. Guidelines D2.8.III.12 Data Specification on Natural Risk Zones-Technical Guidelines, 2013. Available online: https:/ /inspire.ec europa.eu/documents/Data_Specifications/INSPIRE_DataSpecification_NZ_v3.0.pdf (accessed on 11 August 2020).

79. National Climate Change Adaptation Strategy and Action Plan, Ministry of Environment and Water, Bulgaria, 2019. Available online: https:/ / www.moew.government.bg/en/climate/international-negotiations-and-adaptation/adaptation/ (accessed on 5 October 2020).

80. EC. Bulgaria Overview of the National Disaster Management System, 2019. Available online: https://ec.europa.eu/echo/what/ civil-protection/disaster-management/bulgaria_en (accessed on 10 December 2020).

81. Dimitrova, D.; Slavova, V.; Platikanova, M. Unified rescue system in Republic of Bulgaria-organisational structure and management. ЕвразийскийСоюз Ученых(ЕСУ) 2016, 3, 19-23.

82. Dimitrov, D.; Nyagolov, I.; Balabanova, S.; Lisev, N.; Koshinchanov, G.; Korcheva, A.; Marinski, Y.; Pashova, L.; Grozdev, D.; Vasilev, V.; et al. Methods for Assessment of Flood Hazard and Flood Risk, According to Requirements of the EU Flood Directive 2007/60; Final Report, Black Sea Basin Directorate, Contract No D-30-62, 2013; NIMH-BAS: Sofia, Bulgaria, 2013; p. 357. (In Bulgarian)

83. MRDPW. Ministry of Regional Development and Public Works, Methodology for Analysis, Assessment and Mapping of the Seismic Risk of the Republic of Bulgaria. 2018. Available online: https://www.mrrb.bg/bg/metodika-za-analiz-ocenka-ikartografirane-na-seizmichniya-risk-na-republika-bulgariya/ (accessed on 11 November 2020).

84. Dobrev, N.; Bruchev, I.; Nakov, R.; Karastanev, D.; Ivanov, P.; Berov, B.; Krastanov, M.; Frangov, G.; Varbanov, R.; Stoynev, S.; et al. Methodology for Assessment of Geological Risk; Geological Institute and MRDPW: Sofia, Bulgaria, 2014; p. 123. (In Bulgarian) 